\title{
PERFORMANCE OF BROILERS FED LOW PROTEIN DIETS WITH LYSINE AND METHIONINE SUPPLEMENTS
}

\author{
NANCY A. MONTILLA \\ Leyte State University - Villaba Campus \\ Cagnocot, Villaba, Leyte, Philippines
}

and

\section{LOLITO C. BESTIL and SULPECIO C. BANTUGAN}

Department of Animal Science, College of Agriculture

Leyte State University; Visca, Baybay, Leyte, Philippines

\section{ABSTRACT}

A feeding trial with broilers was conducted to evaluate the effects of amino acids (lysine and methionine) supplementation of diets low in protein content on the voluntary intake, feed conversion efficiency, broiler performance, and cost and return of broiler production. Results showed cumulative voluntary feed intake was not significantly affected by lowering the protein content of the diet. Cumulative weight gain of broilers was lower with diets low in protein, but became comparable with that of high-protein diet when supplemented with lysine and methionine to meet requirements. Birds fed with diets low in protein had less efficient feed conversion, but became comparable with those receiving diets high in protein when supplemented with amino acids. Feed cost per kilogram broiler produced was not significantly affected by diets used in the study, although the low-protein diet with amino acid supplement had the lowest values. In terms of return above feed and chick cost, broilers fed with high-protein diet had the greatest value, but not significantly different from birds fed with low-protein diet with amino acid supplementation which gave about P10 per bird higher returns than those fed low-protein diet without amino acid supplementation.

KEYWORDS: Low-protein diets. Amino acid supplement. Broiler performance 


\section{INTRODUCTION}

Broiler-raising in the Philippines has become such a big industry that problems of competition of strain to be raised and brand of feeds to be used have evolved. Where profit is the ultimate goal, feed quality and efficiency of feed utilization are the primary concerns of every broiler raiser as feed constitutes about $70-75 \%$ of the cost of production.

Efficiency in feed utilization can be achieved not only by minimizing waste, but also by efforts to save on feed cost with the use of cheaper formulations without sacrificing quality and acceptability to broilers. The secret of poultry feeding lies in the ability of the poultry raiser to compound a satisfactory ration from available and cheap feed ingredients as well as proper feeding of the ration to birds (Neishem, 1979). A major consideration in the formulation is the adequate supply of protein and the balance of amino acids in the broiler diet.

Supplying the protein needs of poultry is often limited by the high cost of its sources, especially that of animal origin. The use of plant protein sources can save on feed cost, but this has resulted to poorer performance as plant protein sources are known to be deficient in lysine, tryptophan, and threonine (Easter, 1987). Classes (1992) reported that deficiency of essential amino acid in diets adversely affects growth rate and feed conversion efficiency. Even in situations where growth is maximal, improvement in feed conversion efficiency can still be obtained with amino acid supplementation.

Supplementation of synthetic amino lowers the amount of energy needed to metabolize such protein while reducing the incidence of scouring and mortality rate (Cauwenberghe, 1999). Hence, this study 1) evaluated the effect of amino acid (lysine and methionine) supplementation of diets low in protein content on voluntary intake and broiler performance; and 2) determined the efficiency of feed utilization, and the cost and return of broiler production from feeding low-protein diets with amino acids supplementation. 


\section{METHODOLOGY}

\section{Dietary Treatments and Experimental Design}

A total of 90 broiler chicks used in the study were divided into 15 groups corresponding to three treatment diets with five replications each. Treatment-replicates were composed of 6 birds each and were arranged in completely randomized design (CRD). The treatments were as follows:

$\mathrm{A}=$ Ration with $22 \% \mathrm{CP}$ without amino acid supplementation $B=$ Ration with $17 \% \mathrm{CP}$ without amino acid supplementation $\mathrm{C}=$ Ration with $17 \% \mathrm{CP}$ with lysine and methionine supplementation

\section{Preparation of Experimental Diets}

Experimental diets containing high protein $(22 \%)$ and low protein $(17 \%)$ were formulated using tabulated values of nutrient requirements for broilers and nutrient composition of feedstuff published by PCCARD (1988).

Ration 1 (High protein, without synthetic amino acids supplement):

\begin{tabular}{|c|c|c|c|}
\hline Ingredients & Proportion, $\%$ & Ingredients & Proportion \% \\
\hline Ground corn & 27.07 & Soybean mean & 17.66 \\
\hline Corn bran & 11.60 & Ipil-jpil leaf meal & 6.00 \\
\hline Rice bran (D1) & 15.47 & Vegetable oil & 4.66 \\
\hline Coprameal & 14.13 & Dicalcium phosphate & 0.99 \\
\hline Fish meal & 7.07 & Limestone & 0.02 \\
\hline TOTAL & \multicolumn{3}{|c|}{100.00} \\
\hline NUTRIENTS & \multicolumn{2}{|c|}{$\begin{array}{l}\text { COMPOSITION }(\%) \\
\text { Diet A }\end{array}$} & $\begin{array}{l}\text { REQUIREMENT } \\
(\%)\end{array}$ \\
\hline Crude protein (\%) & \multicolumn{2}{|c|}{22} & 22 to 18 \\
\hline M.E (kcal/kg) & \multicolumn{2}{|c|}{2950} & 2950 \\
\hline Calcium (\%) & \multicolumn{2}{|c|}{1.00} & 1.00 \\
\hline Phosphorus (\%) & \multicolumn{2}{|c|}{0.55} & 0.55 \\
\hline Lysine (\%) & \multicolumn{2}{|c|}{1.42} & 1.20 \\
\hline Methionine (\%) & \multicolumn{2}{|c|}{0.45} & 0.45 \\
\hline
\end{tabular}


Ration 2 (Low-protein, with or without synthetic amino acids supplement)

\begin{tabular}{l|c|l|c}
\hline \multicolumn{1}{c|}{ Ingredients } & Proportion (\%) & \multicolumn{1}{c}{ Ingredients } & Proportion (\%) \\
\hline Ground corn & 35.94 & \multicolumn{1}{c}{ Ipil-ipil leaf meal } & 6.00 \\
Corn bran & 15.40 & Vegetable oil & 3.00 \\
Copra meal & 7.681 & Limestone & 0.55 \\
Fish meal & 3.84 & L-lysine & 0.23 \\
Soybean meal & 9.60 & DL-methionine* & 0.12 \\
& \multicolumn{3}{|c}{10.00} \\
\hline \multicolumn{1}{c|}{ TOTAL } & * Added only to Diet C. \\
\hline NUTRIENTS & COMPOSITION (\%) & REQUIREMENTS \\
& Diet B & Diet C & $(\%)$ \\
\hline Crude protein (\%) & 17. & 17 & 22 to 18 \\
M.E. (kcal/kg) & 2950 & 2950 & 2950 \\
Calcium (\%) & 1.00 & 1.00 & 1.00 \\
Phosphorus (\%) & 0.55 & 0.55 & 0.55 \\
Lysine (\%) & 0.98 & 1.20 & 1.20 \\
Methionine (\%) & 0.33 & 0.45 & 0.45 \\
\hline
\end{tabular}

\section{House Preparation}

One week prior to arrival of chicks, the poultry house and its surroundings, including the facilities and equipment, were cleaned and properly disinfected with Lysol. The area was fenced to prevent entry of stray animals.

The house contained 15 cages measuring 6 square feet each of floor space based on the requirement of one square foot per bird (Ensminger, 1977); cages were arranged in single row.

\section{Care and Management of Birds at Brooding}

During the first two weeks, the birds were fed uniformly with chick booster mash containing $24 \%$ crude protein. The drinking water was added with vitamin-mineral premix powder ("Univite", UNIVET) at one (1) teaspoon 
per gallon of water. This was made available to the chicks at all times to promote vitality and resistance to diseases.

A brooder with a floor space of 2.25 square meters was used in brooding the day-old broiler chicks. Before the arrival of the chicks, the brooder was set up to achieve the desired temperature using 50 -watt electric bulbs. Clean old newspapers were utilized as litter material. Temperatures ranging from 90 to $95^{\circ} \mathrm{F}$ in the first two weeks were observed through a thermometer placed inside the brooder.

\section{Feeding and Watering the Birds}

A ration containing $22 \%$ crude protein (CP) without amino acid supplementation was given to birds in treatment $A$, while birds in treatment $B$ were fed with a ration containing $17 \% \mathrm{CP}$ without amino acid supplementation. Birds in treatment $C$ were given a ration containing $17 \%$ $\mathrm{CP}$ supplemented with lysine and methionine. Birds were fed ad libitum 3 times a day at the following time schedule: 7:00 AM, 11:00 AM and 4:00 PM.

The birds were provided with fresh and clean drinking water medicated with vitamin-mineral premix ("Univite", UNIVET) during the following schedule until withdrawn at day 37 onward:

First 21 days (covering period of diet shifts)....Daily

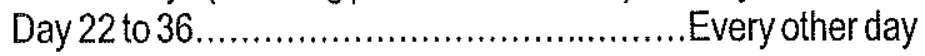

\section{Lighting Program of Experimental Birds}

For the first two weeks of age, the broiler chicks were provided with $24 \mathrm{hr}$ light using a 50-watt bulb to enable them to locate the feeders and waterers as well as to keep them warm and alert at all times. The lighting program was reduced to $12 \mathrm{hr}$, particularly at night, on the third week. On the fourth to sixth weeks of age, light source was reduced to 25-watt bulb provided for $12 \mathrm{hr}$ at night to induce greater feed consumption and better weight gains (Neishem, 1979). 


\section{Data Gathered}

1. Cumulative Voluntary Feed Intake (CVFI)

This was calculated by subtracting the feed refuse from the total amount of feed given on the third up to sixth week of age as follows:

$$
\begin{aligned}
C V F I= & \sum(F G i F R i) \\
\text { where: } & \sum=\text { summation } \\
& F G i=\text { total feed given at } i \text { th period of measurement } \\
& F r i=\text { total feed refused at } i \text { th period of measurement }
\end{aligned}
$$

\section{Cumulative Weight Gain (CWG).}

After brooding for two weeks, all the chicks were weighed and their initial body weights were recorded. The CWG of birds was calculated as:

$$
\begin{aligned}
& C W G=\Sigma(B W i \text { BWo }) \\
& \text { Where: } \Sigma=\text { summation } \\
& \text { BWi }=\text { body weight at ith period of measurement } \\
& \text { BWo }=\text { initial body weight }
\end{aligned}
$$

3. Cumulative Feed Conversion Efficiency (CFCE)

$$
\text { CFCE }=\frac{(C V F I) i}{(C W G) i}
$$

where: $(C V F I) i=$ cumulative voluntary feed intake at $i$ th period.

(CWG)i = cumulative weight gain at $i$ th period. 


\section{Feed Cost per Kilogram of Broiler Produced (FCKBP)}

$$
\text { FCKBP }=\text { Total Feed Cost }
$$

The total feed cost is the cost of the chick booster mash in the first two weeks of age and cost of experimental diets from the third until the sixth week of age, and was calculated as follows:

$$
\text { Total Feed Cost }=\text { CVFi, } \mathrm{kg} \times \text { Price } / \mathrm{kg} \text { feed }
$$

5. Return Above Feed and Chick Cost (RAFCC)

$$
\begin{aligned}
\text { RAFCC }= & \text { (Final weight } x \text { Price } / \mathrm{kg} \text { Final Weight }) \text { Chick } \\
& \text { Cost }- \text { Total Feed Cost }
\end{aligned}
$$

\section{Analysis of Data}

The data on CVFI, CWG, FCE, FCKBP, and RAFCC were analyzed using the one-way analysis of variance (ANOVA). Differences in treatment means were compared using Duncan's Multiple Range Test (DMRT).

\section{RESULTS AND DISCUSSION}

\section{Cumulative Voluntary Feed Intake}

The reduction in protein content in the diet, and consequently lysine and methionine contents, was not enough to effect reduction in voluntary feed intake (Table 1). The most probable explanation is the use of fish meal (an animal protein source), which is expected to have a better balance of amino acids, as one of the ration ingredients. This is supported by Rojas (1997) who said that reduction in protein content of the diet and the need for amino acid supplementation is only critical when using plant protein sources. Even Cauwenberghe (1999) noted a decrease in voluntary feed intake only 
during severe deficiencies of amino acids, and added that moderate deficiencies may even cause increases in voluntary feed intake. As feeding trial started only after the brooding period (on the third week); the $17 \%$ crude protein (CP) content of the diet used in this experiment was not too low if compared with the requirements of $20 \% \mathrm{CP}$ at $2-5$ weeks and $18 \% \mathrm{CP}$ at $5-8$ weeks of age (PCCARD 1988).

Table 1. Cumulative voluntary feed intake $(\mathrm{kg})$ of broilers fed diets low in protein with or without amino acid supplementation.

\begin{tabular}{l|c|c|c|c}
\hline \multirow{2}{*}{ Treatment Diets } & \multicolumn{4}{|c}{ Age of broilers, weeks } \\
\cline { 2 - 5 } & 3 & 4 & 5 & 6 \\
\hline $\mathrm{A}(22 \% \mathrm{CP})$ & 0.4294 & 0.9710 & 1.6192 & 2.4088 \\
$\mathrm{~B}(17 \% \mathrm{CP})$ & 0.4158 & 0.9766 & 1.6225 & 2.4034 \\
$\mathrm{C}(17 \% \mathrm{CP}+$ Amino & 0.4230 & 0.9768 & 1.6252 & 2.4400 \\
acids) & & & & \\
\hline C.V. $(\%)$ & 1.99 & 1.56 & 0.99 & 0.68 \\
\hline \hline
\end{tabular}

No letters means "no significant difference at $5 \%$ level".

\section{Cumulative Weight Gain}

There was no significant effect of the reduction of protein level of diets with or without amino acid supplementation, except in week 3 (Table 2). However, broilers fed diet B (low-protein without amino acid supplement) had apparently and consistently lower weight gains than those fed diets $A$ (high-protein without amino acid supplement) and C (low-protein with lysine and methionine). In fact, such weight gains were observed to be significantly lower $(P>0.05)$ than those in birds fed $\operatorname{diets} A$ and $C$. These results conformed to the findings of Cauwenberghe (1999). The findings of Daghir (1983) supported this when he found that broilers are not significantly affected by reduction in protein level of diet with amino acids (particularly lysine and methionine) supplementation. Tan (1988) made similar conclusion to support this reduction even by as much as two percentage units. 
Table 2. Cumulative weight gain $(\mathrm{kg})$ of broilers fed diets low in protein with or without amino acid supplementation.

\begin{tabular}{l|c|c|c|c}
\hline \multirow{2}{*}{ Treatment Diets } & \multicolumn{4}{|c}{ Age of broilers, weeks } \\
\cline { 2 - 5 } & 3 & 4 & 5 & 6 \\
\hline $\mathrm{A}(22 \% \mathrm{CP})$ & 0.2084 & 0.5532 & $0.9850 \mathrm{a}$ & 1.3844 \\
$\mathrm{~B}(17 \% \mathrm{CP})$ & 0.1958 & 0.4640 & $0.8350 \mathrm{~b}$ & 1.0828 \\
$\mathrm{C}(17 \% \mathrm{CP}+$ Amino & 0.2186 & 0.5034 & $0.9468 \mathrm{ab}$ & 1.2426 \\
acids) & & & & \\
\hline C.V. (\%) & 4.65 & 2.60 & 1.58 & 4.57 \\
\hline \hline
\end{tabular}

Means of the same letters are not significantly different at $5 \%$ level. Noletters means "no significant difference".

\section{Cumulative Feed Conversion Efficiency}

Cumulative feed conversion efficiency (CFCE) measures the amount $(\mathrm{kg})$ of feed required to produce one kilogram of weight gain. Birds fed with high-protein diet (Diet A) and those fed with low-protein diet with lysine and methionine supplementation (Diet $\mathrm{C}$ ) were found to be significantly efficient $(P>0.05)$ than birds fed low-protein diet without amino acid supplement (Diet B) (Table 3). This means that reducing the crude protein content of the diet lowers feed conversion efficiency, but providing amino acid supplement to low-protein feeds improves the efficiency of feed conversion of broilers. This suggests that providing amino acid supplementation to low-protein diets improve growth pattern more than it does on voluntary feed intake, and is comparable to the more costly, high protein feeds. The most probable explanation is the better balance of amino acids that was achieved in highprotein diet (especially containing fish meal) and in low-protein diet with lysine and methionine supplementation that are usually limiting in most diets of poultry as supported by the findings of Daghir (1983) and Sison (1988). 
Table 3. Cumulative feed conversion efficiency (CFCE) of broilers fed diets low in protein with or without amino acid supplementation.

\begin{tabular}{l|c|c|c|c}
\hline \multirow{2}{*}{ Treatment Diets } & \multicolumn{4}{|c}{ Age of broilers, weeks } \\
\cline { 2 - 5 } & 1 & 2 & 3 & 4 \\
\hline $\mathrm{A}(22 \% \mathrm{CP})$ & 1.5908 & 1.7682 & $1.6562 \mathrm{~b}$ & $1.7498 \mathrm{c}$ \\
$\mathrm{B}(17 \% \mathrm{CP})$ & 2.2250 & 2.1520 & $1.9462 \mathrm{a}$ & $2.2206 \mathrm{a}$ \\
$\mathrm{C}(17 \% \mathrm{CP}+$ Amino & 2.0056 & 1.9674 & $1.7230 \mathrm{~b}$ & $1.9536 \mathrm{~b}$ \\
acids) & & & & \\
\hline C.V. (\%) & 5.66 & 3.29 & 1.63 & 1.19 \\
\hline \hline
\end{tabular}

Means of the same letters are not significantly different at $5 \%$ level.

No letters means "no significant difference".

\section{Cost and Return Analysis}

It can be gleaned from the results (Table 4) that differences in FCKBP were not significant, although treatment diet $C$ had the lowest. Nevertheless, a little saving on feed cost would mean more to the farmer than its statistical significance. The difference of about $\mathrm{P} 0.40$ per kilogram broiler between diet $C$ and $A$ would mean savings of about $P 6,000.00$ for a contract-grower of 10,000 birds, and such savings was more than double comparing between $\operatorname{diet} C$ at the final liveweight of $1.5 \mathrm{~kg}$, and $\operatorname{diet} B$.

In terms of RAFCC, birds fed with $22 \%$ crude protein (Diet A) gave the highest than the rest of the treatments. However, this value is not significantly different from that of birds fed with $17 \%$ crude protein with amino acid supplements (Diet C). This means that supplementing amino acids can compensate for the reduction in crude protein content of the diet. 
Table 4. Feed cost per kilogram broiler produced (FCKBP) and return above feed and chick costs (RAFCC) of broilers fed diets low in protein with or without amino acid supplementation.

\begin{tabular}{l|c|c}
\hline \hline Treatment Diets & FCFBP (Pesos) & RAFCC (Pesos) \\
\hline & & \\
A $(22 \% \mathrm{CP})$ & 24.48 & $55.86 \mathrm{a}$ \\
$\mathrm{B}(17 \% \mathrm{CP})$ & 24.09 & $39.88 \mathrm{~b}$ \\
C $(17 \% \mathrm{CP}+$ Amino & 24.97 & $49.15 \mathrm{ab}$ \\
acids & & \\
\hline \multicolumn{1}{c|}{ C.V. (\%) } & 0.35 & 3.62 \\
\hline
\end{tabular}

Means of the same letters are not significantly different at $5 \%$ level. No letters means "no significant difference".

\section{CONCLUSION AND RECOMMENDATION}

\section{Conclusion}

Feeding broilers with diets containing $17 \%$ crude protein with amino acid supplementation is comparable to high-protein diets in terms of growth rate, efficiency of feed conversion, and rate of return. One added advantage is that it is lower in cost. The feeding of diets containing $17 \%$ crude protein or lower without amino acid supplementation is limiting, both in terms of growth performance and economic returns of broiler production.

\section{Recommendation}

Where supply of high-protein feeds is inadequate, and price and transport cost restrict usage, the feeding of diets low in protein with amino acid supplementation is highly recommended.

It is also recommended to further evaluate the response of broilers given low-protein diets to amino acids supplementation at different stages of development where protein requirements vary. 


\section{LITERATURE CITED}

CAUWENBERGHE, S. V. 1999. Low protein diets: Why and how?. In Proc.:

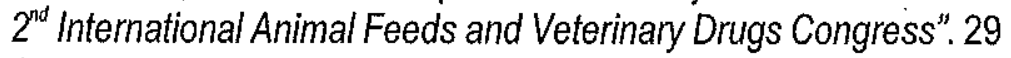
June to 2 July 1999. Manila, Philippines. T.M Specialists Press. 113F. Manalo St., Cubao, Quezon City, Philippines.

CLASSES, H.L 1992. Non-genetic aspects of feed efficiency. Agribusiness. Mr. \& Mrs. Publishing Company, Manila, Philippines. 4 (45):23.

DAGHIR, N.J. 1983. Effect of lysine and methionine supplementation of lowprotein roaster diets fed after six days of age. Poultry Sci. 62(8):15721575.

EASTER, R.E. 1987. Local materials used in feed formulation. Animal Feed Service Bulletin. Bureau of Animal Industry. Diliman Quezon City, Philippines. p.18.

ENSMINGER, M.E. 1977. Animal Science. $7^{\text {th }}$ edition. The Interstate Printers \& Publishers, Inc. Danville, Illinois, USA.

NEISHEM, M. 1979. Poultry Production. $12^{\text {th }}$ ed. Lea \& Febiger Publishing Co., USA. p. 168.

PCARRD. 1988. The Philipine Recommends for Livestock Feed Formulation. PCARRD Tech. Bull. Series No. 64. Philippine Council for Agriculture, Forestry and Natural Resources Research and Development. Los Baños, Laguna, Philippines. 128p.

ROJAS, A.G. 1998. Amino Acid Supplementation to Plant Protein-Based Broiler Starter and Finisher Diets. BS Thesis. VISCA, Baybay, Leyte, Philippines, 
SISON, J.A. 1988. Synthetic amino acids. Agribusiness. Mr \& Mrs. Publishing Company, Manila, Philippines. 3(40).

\section{ABOUT THE AUTHOR}

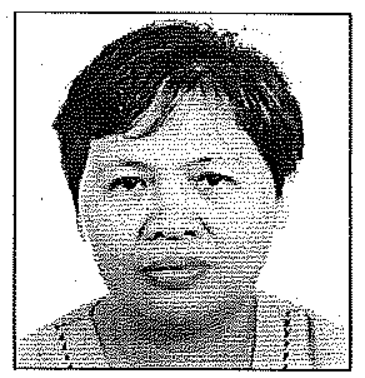

The author obtained her B.S. in Agricultural Education major in Animal Husbandry at Leyte National Agricultural College (LNAC) in Villaba, Leyte (now LSU-Villaba Campus) in 1980. She worked at LNAC as Secondary School Teacher in 1981, and promoted to Instructor I in 1991. She finished her Master of Agricultural Development major in Animal Production in 2001 at the Visayas State College of Agriculture (now Leyte State University).

The co-authors are professors of the Department of Animal Science (DAS), College of Agriculture, Leyte State University. 